\title{
Effect of thermal environment on performance of broiler chickens using fuzzy modeling
}

\author{
Flávio Alves Damasceno ${ }^{1 *}$, Déborah Cunha Cassuce ${ }^{2}$, Lucas Henrique Pedrozo Abreu ${ }^{1}$, \\ Leonardo Schiassi ${ }^{1}$, Ilda de Fátima Ferreira Tinôco ${ }^{3}$
}

10.1590/0034-737X201764040001

\begin{abstract}
This study aimed to develop a decision-support system based on fuzzy set theory, which can estimate welfare depending on the production responses of broiler chickens raised in climatic chambers. In the first phase, the influence of four different air temperature conditions on the performance of broilers was identified. Thus, the effect of air temperature on productivity was evaluated. In the second phase, a model was developed using the fuzzy set theory, in which feed intake responses, weight gain, and feed conversion were established according to age and the air temperature at which the birds were maintained, obtaining an efficient evaluation of the thermal environment. The results indicate that the proposed methodology is a promising technique for the determination of the level of thermal comfort endured by broilers, capable of assisting in making decisions on control of the thermal environment, avoiding productivity losses.
\end{abstract}

Key words: mathematical models; environmental comfort; climatic chambers.

\section{RESUMO}

\section{Efeito do ambiente térmico sobre o desempenho de frangos de cortes usando modelagem fuzzy}

Este estudo teve como objetivo desenvolver um sistema de apoio à decisão com base na teoria dos conjuntos fuzzy, que pode estimar o bem-estar de acordo com as respostas de produção de frangos de corte criados em câmaras climatizadas. Na primeira fase, identificou-se a influência de quatro diferentes condições de temperatura do ar sobre o desempenho dos frangos. Assim, foi avaliado o efeito da temperatura do ar na produtividade. Na segunda fase, foi desenvolvido um modelo usando a teoria dos conjuntos fuzzy, onde as respostas consumo de ração, ganho de peso e conversão alimentar foram estabelecidos de acordo com a idade e a temperatura do ar em que as aves foram mantidas, para obtenção de uma avaliação eficaz do ambiente térmico. Os resultados indicaram que a metodologia proposta é uma técnica promissora para a determinação do nível de conforto térmico sofrido por frangos de corte, capazes de auxiliar na tomada de decisões sobre o controle do ambiente térmico, evitando perdas de produtividade.

Palavras-chave: modelos matemáticos; conforto ambiental; câmaras climáticas.

\footnotetext{
Submitted on December 05 $5^{\text {th }}, 2015$ and accepted on July $18^{\text {th }}, 2017$.

' Universidade Federal de Lavras, Departamento de Engenharia, Lavras, Minas Gerais, Brazil. flavio.damasceno@deg.ufla.br; lhpabreu@gmail.com; leonardo.schiassi@deg.ufla.br

${ }^{2}$ Instituto Federal do Espírito Santo, Campus Itapina, Itapina, Espírito Santo, Brazil. deborah.cassuce@ifes.edu.br

${ }_{3}^{3}$ Universidade Federal de Viçosa, Departamento de Engenharia Agrícola e Ambiental, Viçosa, Minas Gerais, Brazil. iftinoco@ufv.br

*Corresponding author: flavio.damasceno@deg.ufla.br
} 


\section{INTRODUCTION}

In Brazil, the percentage of days in the year with weather conditions considered comfortable for the birds is higher compared with the US and Europe. However, production systems developed in these countries have been introduced in Brazil without any significant change, leading the poultry producers to a reduction in production competitiveness, besides imposing heat stress situations on the birds (Medeiros, 2001; Almeida \& Passini, 2013).

The high environmental temperature values have been causing serious problems in the poultry industry due to a decline in production and the high mortality. High mortality rates and other economical losses happens during the first weeks of broiler rearing, emphasizing that incorrect management and environmental control routines at this stage may cause significant losses (Baracho et al., 2006; Heier et al., 2002).

The level of thermal comfort inside poultry houses is a highly important factor in determining the success of broiler production activity (Lopes et al., 2015). Excess cold and/or heat results in lower productivity of the birds, affecting their overall performance and health, and extreme situations may occur, with the addition of high mortality.

For this reason, it is very important to know the thermal levels considered comfortable and appropriate for the maximum growth performance of broilers in their different development stages (Nascimento et al., 2011). Furthermore, it is believed that the temperature ranges currently established as optimal for the standard lines of birds may be outmoded due to the genetic and nutritional changes, as well as to their acclimation to the local weather conditions (Medeiros, 2001).

In order to quantify the interaction of the thermal variables in the comfort of the birds, one can make use of computational models, such as those known as intelligent expert systems, which are able to perform tasks or solve problems from a knowledge base. The most used and tested are the logical, fuzzy, and artificial neural networks (Schiassi et al., 2012).

Expert systems based on fuzzy set theory are alternatives for the management of uncertainties in the poultry environment. They have been applied to evaluate animal welfare (Pandorfi et al., 2007) and growth performance of broiler chickens (Schiassi et al., 2015; Ponciano et al., 2012), production cost analysis (Nääs et al., 2010), monitoring systems for electricity transmission networks (Almeida \& Kagan, 2010), estrus detection in dairy cows (Ferreira et al., 2007), and workers in intensive systems (Schiassi et al., 2012).

Faced with the versatility displayed by this computational mathematics tool, this study aimed to develop a decision support system based on fuzzy set theory, which can estimate welfare depending on the production responses of broiler chickens raised in climatic chambers.

\section{MATERIALAND METHODS}

\section{Data collection and animal management}

This study was developed in two stages:

a) In the first stage, we evaluated the representative range of thermal comfort for broilers of different ages, acclimatized in Brazilian climatic conditions, verifying the influence of different cold- and heat-stress temperatures in the early stages of breeding on productive performance of the birds subjected to comfort or different conditions of heat stress.

For this, we used five climatic chambers with dimensions of $2.5 \mathrm{~m}$ wide $\times 3.3 \mathrm{~m}$ long $\times 2.5 \mathrm{~m}$ high, located in the Center for Research on the Environment and Agro-Industrial System Engineering (AMBIAGRO), Rural Construction and the Environmental Sector of the Departmento de Engenharia Agrícola (Agricultural Engineering Department) of the Universidade Federal de Viçosa (UFV).

Each climatic chamber was equipped with a split-type hot/cold air conditioner of 12,000 BTU h ${ }^{-1}$, an electrical resistance heater of $2000 \mathrm{~W}$, and a humidifier with a capacity of $4.5 \mathrm{~L}$, and mist flow (average value) of $300 \mathrm{~mL} \mathrm{~h}^{-1}$. The heater and humidifier were controlled by an electronic temperature and humidity controller. The hygienic ventilation applied inside the environmental chambers was performed by means of axial exhaust, with automatic activation, to allow four air changes per hour throughout the experimental period, meaning a renewal every $15 \mathrm{~min}$.

Six hundred male Cobb broilers were used, with uniform weights and originating from the same hatchery. The birds were randomly distributed in the five climatic chambers. Each climatic chamber had six commercial cages with dimensions of $0.5 \mathrm{~m}$ wide $\times 1.0 \mathrm{~m}$ long $\times 0.5 \mathrm{~m}$ height, in which 20 one-day-old birds were initially housed.

The supply of water and food to the birds was performed ad libitum twice a day, at 8:00 and 16:00 h, in order to keep the waterers and feeders always stocked. Waterers were the pressure-cup type throughout the initial phase and manually filled at the same times as feeding. Two kinds of commercial feed were provided during the breeding period, called: pre-starter feed (birds from 1 to 7 days old) and starter feed (birds from 8 to 21 days of age). The light program adopted was continuous with $1 \mathrm{~h}$ of darkness and $23 \mathrm{~h}$ of light throughout the experimental period, with two fluorescent lamps, following the standards normally used in commercial farms.

Thus, considering the changing thermal requirements due to the growth of the birds, five different ranges of thermal conditions were set up to be implemented in each 
of the climate chambers during the first three weeks of bird life:

- Treatment $27_{(24-21)}$ Stress defined as intense cold: 27 ${ }^{\circ} \mathrm{C}$ in the first week, $24{ }^{\circ} \mathrm{C}$ in the second week, and $21^{\circ} \mathrm{C}$ in the third week;

- Treatment $30_{(27-24)}$ Stress defined as moderate cold: $30^{\circ} \mathrm{C}$ in the first week, $27^{\circ} \mathrm{C}$ in the second week, and 24 ${ }^{\circ} \mathrm{C}$ in the third week;

- Treatment $33_{(30-27)}$ Comfort: $33^{\circ} \mathrm{C}$ in the first week, $30{ }^{\circ} \mathrm{C}$ in the second week, and $27^{\circ} \mathrm{C}$ in the third week;

- Treatment 36 $(33-30)$ Stress defined as moderate heat: $36{ }^{\circ} \mathrm{C}$ in the first week, $33^{\circ} \mathrm{C}$ in the second week, and 30 ${ }^{\circ} \mathrm{C}$ in the third week; and

- Treatment $39_{(\mathbf{3 6 - 3 3 )}}$ Stress defined as intense heat: 39 ${ }^{\circ} \mathrm{C}$ in the first week, $36{ }^{\circ} \mathrm{C}$ in the second week, and $33{ }^{\circ} \mathrm{C}$ in the third week;

The air relative humidity values inside the climatic chambers for all treatments was established at around $60 \%$, considered an appropriate value for poultry production, regardless of the age of the birds and ambient temperature, according to some studies (Tinôco, 2004; Medeiros, 2005).

For the control and monitoring of the thermal environment within each climatic chamber, the air temperature values $\left(\mathrm{T}_{\mathrm{db}}\right)$ and relative humidity $(\mathrm{RH})$ were automatically controlled through humidifiers, heaters, axial air conditioners, and exhaust fans, as described above. The thermal environment data within each climate chamber were recorded daily every $5 \mathrm{~min}$ by means of sensors/ recorders (Testo ${ }^{\circledR}$, Mod. 608-H1 and resolution $\pm 0.1^{\circ} \mathrm{C}$ ).

Productive variables (average feed intake - FI; mean weight gain - WG; and the average feed conversion - FC) were analyzed weekly and 10 birds were evaluated from each treatment each week. In this case, each bird was considered one trial. To determine the WG, a digital scale was used. The WG was obtained by the difference between the initial and final weights (day-old birds) divided by the age of the birds. Feed conversion, at the end of each batch, was obtained by the ratio between the total weight of feed consumed $(\mathrm{kg})$ by total weight of live broilers at the end of slaughter age $(\mathrm{kg})$.

\section{Fuzzy Model Development}

b) In the second stage, the data of the thermal environment collected in the climate chambers was used to develop the fuzzy model to predict the productive responses of the birds (FI, WG, and FC).

For this, the data from each treatment was tabulated and used to determine the accumulated values of FI (g), $\mathrm{WG}(\mathrm{g})$, and FC $\left(\mathrm{g} \cdot \mathrm{g}^{-1}\right)$, which were used also in validation of the fuzzy model proposed.
For each variable, fuzzy sets that characterized them were assigned, in which a membership function was created for each fuzzy set. Seeking to quantify the importance of temperature variation in the second week of life, input variables used were age of birds ( $\mathrm{S}$, days), called age $\mathrm{S} 1$ [1-8 days], S2 [7-15 days], and S3 [14 to 21 days], and the air temperatures $\left(\mathrm{T},{ }^{\circ} \mathrm{C}\right)$, which was classified into $\mathrm{T} 1$ [ 27 to $30^{\circ} \mathrm{C}$ ], T2 [27 to $33^{\circ} \mathrm{C}$ ], T3 [ 30 to $36^{\circ} \mathrm{C}$ ], and $\mathrm{T} 4\left[33\right.$ to $36^{\circ} \mathrm{C}$ ]. Thus, the intervals were determined for each input variable, as can be seen from Table 1 and their relevance curves (Figure 1). The ranges accepted for input variables $(\mathrm{S}, \mathrm{T})$ are listed in Table 1 and those shown were represented in triangular shape for the air temperature input variable and trapezoidal for age because of better representing input data classes, solutions found by several authors (Schiassi et al, 2015; Ponciano et al., 2012; Nascimento et al., 2011; Pereira et al., 2008).

The relevance curves for the output variables (Figure 2) were developed based on research conducted (Thon et al., 2010; Lira et al., 2009; Medeiros, 2001) and books about the breed adopted in this study (Cobb, 2012), which provided information about the productive responses in the three initial weeks, four air temperature classes, totaling 12 rules, which include the conditions for the first three weeks of bird life.

To develop the design of the system, it was necessary to determine the outputs that the model will predict, which were defined as: feed intake $(\mathrm{g})$, weight gain $(\mathrm{g})$, and feed conversion $\left(\mathrm{g} \mathrm{g}^{-1}\right)$. These parameters, which determine the productive performance of broiler chickens, were analyzed for 21 days, and to develop the model, the accumulated values were used during this period.

The rules (Table 2) were defined in linguistic sentences, based on data collected in the first phase of this experiment and with the help of three specialists, and integrate a substantial feature in the performance of a fuzzy inference system that will perform well only when the rules are consistent (Schiassi et al., 2015). Thus, for the development of fuzzy logic, it is necessary that the professional be qualified to avoid possible contradictions in the interactions between the rules. According to the combination of duration and temperature of thermal stress, 12 rules are defined and for each rule, a weighting factor of 1 was assigned, as adopted by Ponciano et al. (2012) and Yanagi Junior et al. (2012).

For output variables, the relevance curves were characterized as triangular (Figure 2), for reproducing better responses with the smaller standard deviation values, and thus, are used by several authors (Pereira et al., 2008; Ponciano et al., 2012).

To accomplish all fuzzy reasoning, the Mamdani inference method was applied, which provides the responses of a set according to the combinations of input 
values with their relative degrees of relevance through a minimum operator, and then by the definitions of the rules by the maximum operator. The method of center of gravity (centroid or center area) was used in defuzzification, in which all output alternatives are admitted, converting the sets into numerical values (Leite et al., 2010).

In this work, we used the methodology proposed by Cornelissen et al. (2002), for selecting the specialist as used by Yanagi Junior et al. (2012). Thus, three experts having experience of more than ten years in animal environment and fuzzy modeling helped in assembling the rules.

\section{RESULTS AND DISCUSSION}

The first two weeks of bird life are the most critical because mistakes made at this stage cannot be corrected satisfactorily in the future, thus affecting the final performance of the birds (Cordeiro et al., 2010). For this reason, the thermal environment must adapt to the ideal conditions of welfare for younger birds.

Table 1: Fuzzy sets for the input variables

\begin{tabular}{|c|c|c|c|c|c|c|}
\hline \multicolumn{3}{|c|}{ Age (days) } & \multicolumn{4}{|c|}{ Air temperature $\left({ }^{\circ} \mathrm{C}\right)$} \\
\hline $\mathbf{S 1}$ & $\mathbf{S 2}$ & S3 & T1 & $\mathbf{T 2}$ & T3 & T4 \\
\hline$[1 ; 8]$ & {$[7 ; 15]$} & {$[14 ; 21]$} & {$[27 ; 30]$} & {$[27 ; 33]$} & {$[30 ; 36]$} & {$[33 ; 36]$} \\
\hline
\end{tabular}

A

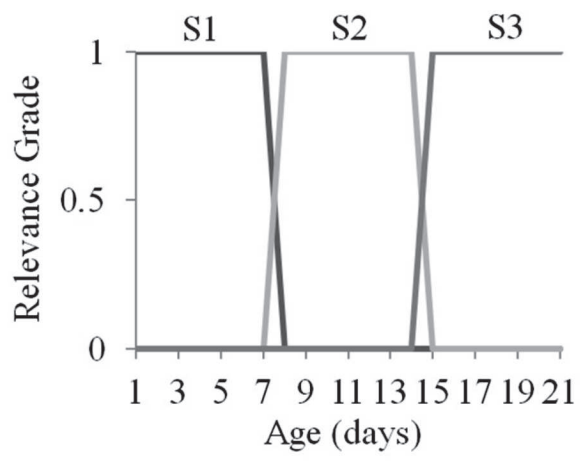

B

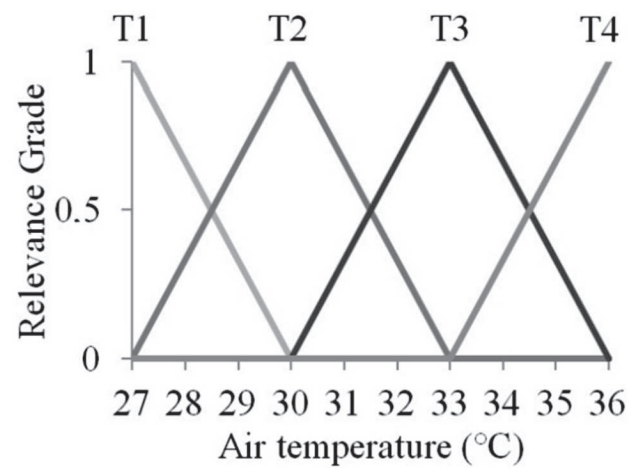

Figure 1: Relevance curves of input variables (age and air temperature) for fuzzy logic.

A

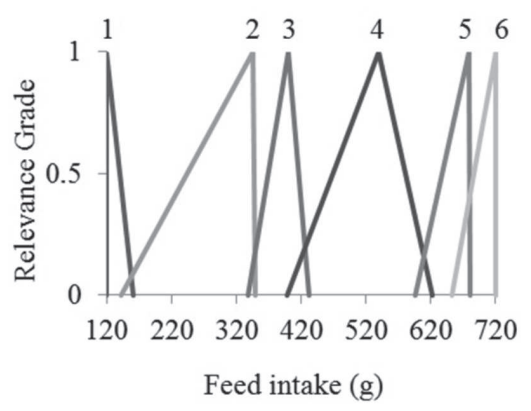

C

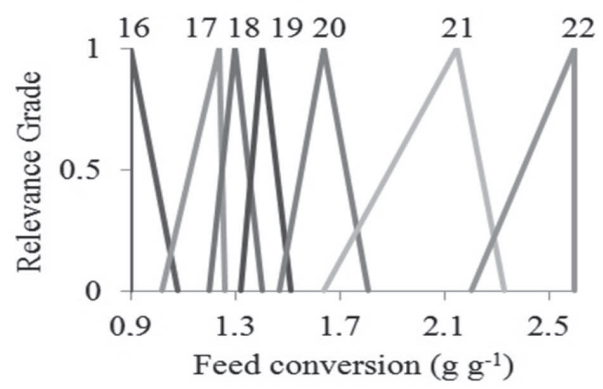

B

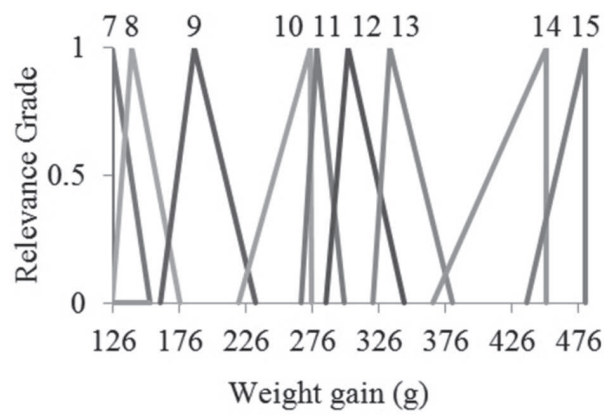

D

$\begin{array}{cc}1 \text { to } 6 & \begin{array}{r}\text { Feed intake relevance curves } \\ 7 \text { to } 15\end{array} \\ \text { Weight gain relevance } \\ \text { curves }\end{array}$

Figure 2: Membership functions for the output variables feed intake, weight gain, and feed conversion. 
According to Oliveira et al. (2006), the ideal temperature range for broilers is, in the first weeks of life, between 32-34 ${ }^{\circ} \mathrm{C}$, reducing gradually to reach $27^{\circ} \mathrm{C}$ in the final phase of the experiment, at 21 days of age. Overall, as can be seen from Table 3, the best results, WG and, FC were observed during the first two weeks of life in conditions of $30-33{ }^{\circ} \mathrm{C}$. In the third week of life, the maximum $\mathrm{WG}$ and the best FC were achieved in the conditions of approximately $27^{\circ} \mathrm{C}$.

According to Boiago et al. (2013), one of the effects of heat stress on the birds leads to substantial losses is the reduction of FI because the birds try to decrease internal heat production due to intake of energy from the feed. The results of this work are similar to those found by Oliveira et al. (2006), working with 1-21-day-old broilers, observed a $14 \%$ reduction in FI in birds kept in hightemperature environments.

Silva et al. (2009), evaluating the performance of 1-21day-old broilers raised at different temperatures, concluded that the high temperature in stage 1-7 days old increased FC, which presented the best values in control

Table 2: System of fuzzy inference rules for age and temperature

\begin{tabular}{ll}
\hline & \multicolumn{1}{c}{ Rule } \\
\hline 1 & If (Age is D1) and (temperature is T1), then (WG is 7) and (FI 1) and (FC is 16) \\
2 & If (Age is D1) and (temperature is T2), then (WG is 8) and (FI 1) and (FC is 16) \\
3 & If (Age is D1) and (temperature is T3), then (WG is 8) and (FI 1) and (FC is 16) \\
4 & If (Age is D1) and (temperature is T4), then (WG is 7) and (FI 1) and (FC is 16) \\
5 & If (Age is D2) and (temperature is T1), then (WG is 13) and (FI 3) and (FC is 17) \\
6 & If (Age is D2) and (temperature is T2), then (WG is 12) and (FI 3) and (FC is 18) \\
7 & If (Age is D2) and (temperature is T3), then (WG is 11) and (FI 3) and (FC is 19) \\
8 & If (Age is D2) and (temperature is T4), then (WG is 9) and (FI 2) and (FC is 19) \\
9 & If (Age is D3) and (temperature is T1), then (WG is 15) and (FI 5) and (FC is 19) \\
10 & If (Age is D3) and (temperature is T2), then (WG is 14) and (FI 6) and (FC is 20) \\
11 & If (Age is D3) and (temperature is T3), then (WG is 12) and (FI 5) and (FC is 21) \\
12 & If (Age is D3) and (temperature is T4), then (WG is 10) and (FI 5) and (FC is 22) \\
\hline
\end{tabular}

WG - weight gain; FI - feed intake; FC - feed conversion.
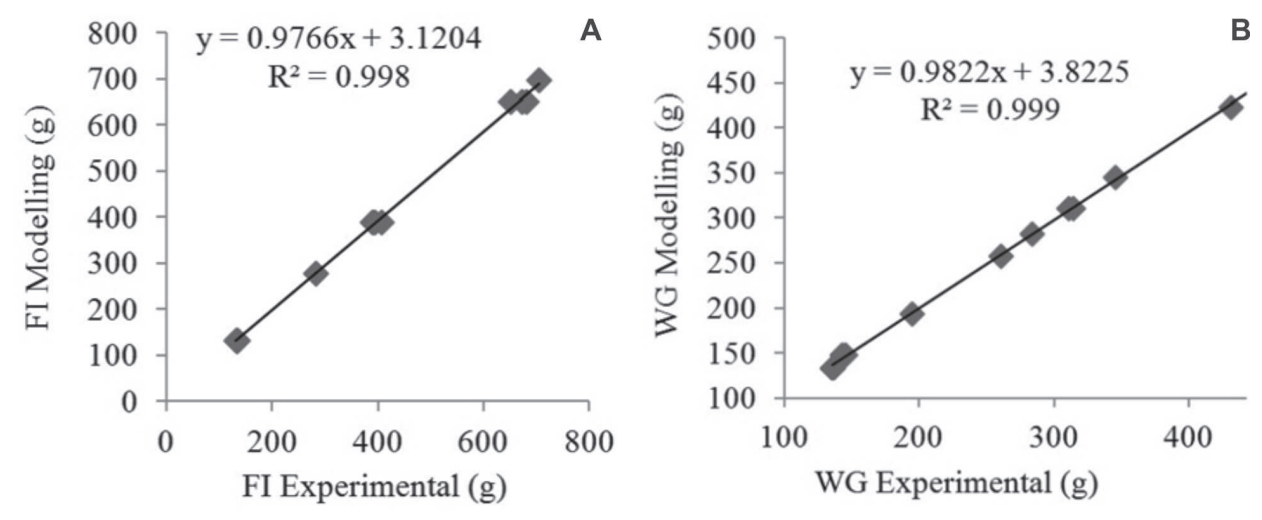

B

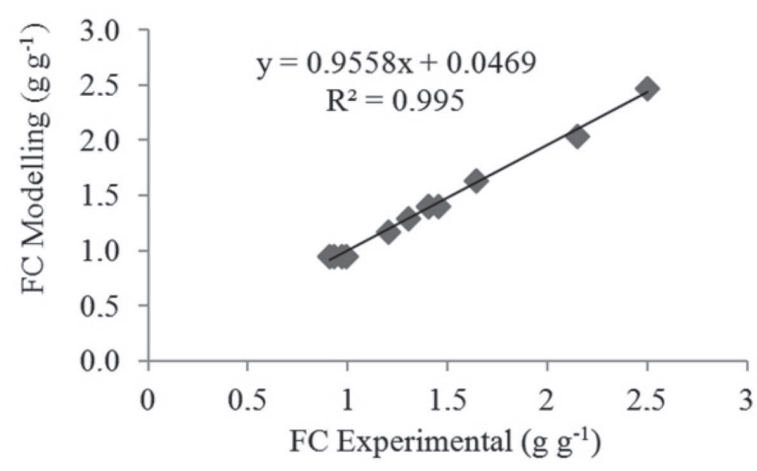

C

FI - feed intake; WG - weight gain; FC - feed conversion.

Figure 3: Linear regressions of the productive variables observed and simulated by the fuzzy model for 1-21-day-old broilers. 
and low temperatures. In the second week of life, the thermal comfort temperature range recommended by the same authors previously cited is between $28-32{ }^{\circ} \mathrm{C}$ and in the third week, between $26-28^{\circ} \mathrm{C}$.

The average standard deviations of the variables FI, WG, and FC were $4.77 \mathrm{~g}, 1.41 \mathrm{~g}$, and $1.88 \mathrm{~g} \mathrm{~g}^{-1}$, respectively, corresponding to the percentage error measured of 1.20, 0.02 , and $2.17 \%$ (Table 3). According to the linear regressions, with straight adjustment through the origin, $\mathrm{R}^{2}=0.998,0.999$, and 0.995 for FI, WG, and FC, respectively (Figure 3). These results indicated good accuracy of the fuzzy model.

In research conducted by Ponciano et al. (2012) to predict the productive performance of 1-21-day-old broilers, using the mathematical model, average values of standard deviations were obtained of $4.77 \mathrm{~g}, 1.41 \mathrm{~g}$, and $1.88 \mathrm{~g} \mathrm{~g}^{-1}$, respectively, and percentage errors of 1.2 , 0.02 , and $2.17 \%$, thus demonstrating the efficiency of the fuzzy model, proposed to simulate the productive responses.

In Figure 3, linear regressions of the values obtained experimentally and by fuzzy modeling were adjusted, in which the coefficients of determination $\left(\mathrm{R}^{2}\right)$ shown for FI, WG, and FC were $0.998,0.999$, and 0.995 , respectively. To evaluate the performance of adult broiler chickens as a function of temperature, relative humidity, and air velocity, Medeiros et al. (2005) developed a mathematical model to predict the FI, WG, and FC and found values for determination coefficients of $0.91,0.89$, and 0.72 , respectively.

The surface shown in Figure 4 illustrates the interaction between temperature and duration of thermal stress considering the FC. The analysis can be made with

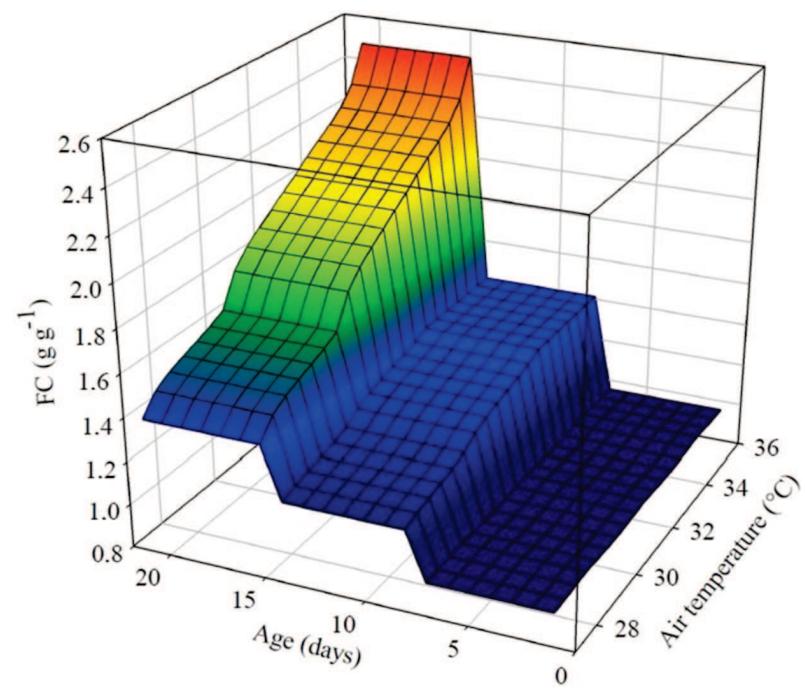

Figure 4: Feed conversion (FC) simulated as a function of thermal stress temperature and duration of thermal stress for 1-21-dayold broilers.

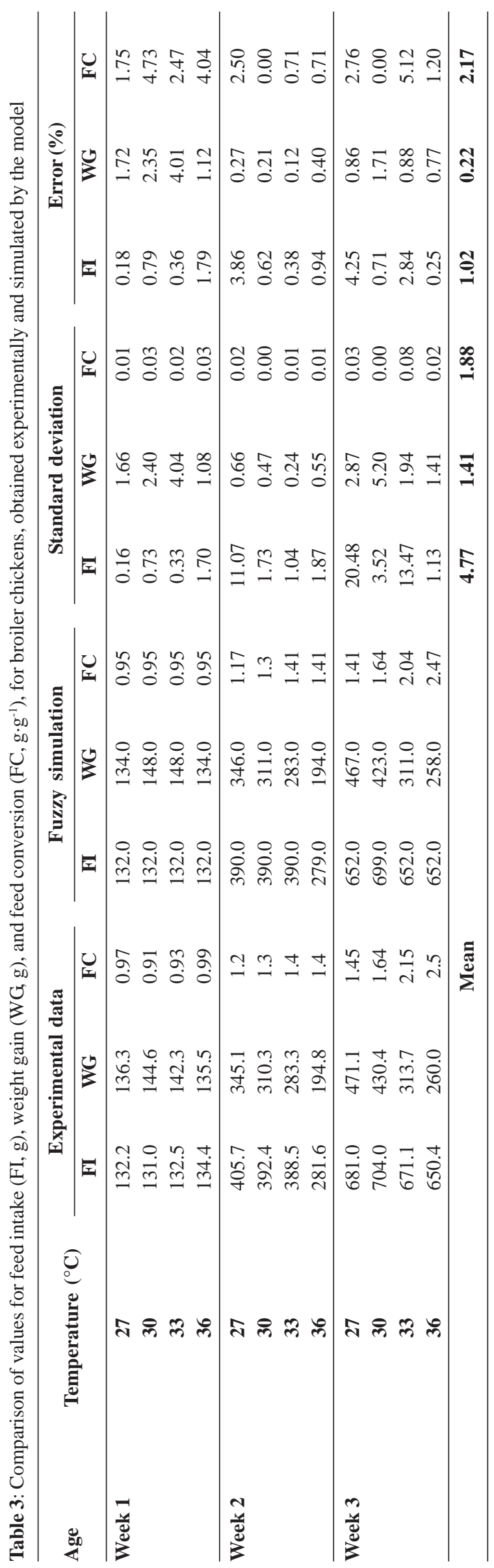


respect to the days of thermal stress and temperature adopted.

\section{CONCLUSIONS}

The results indicated that the Fuzzy model is a promising technique for estimating the level of thermal comfort for broilers, able to assist in making decisions about the control of the thermal environment and avoid productivity losses.

This research, performed in a controlled environment, allowed investigation of the influence of air temperature, depending on the age of the birds, on production responses during the study period.

\section{ACKNOWLEDGMENTS}

The authors wish to thank the producers for their participation in the study and also FAPEMIG, CNPq, CAPES, and the Departmento de Engenharia Agrícola (Agricultural Engeneering Department) of Universidade Federal de Viçosa, for financial support.

\section{REFERENCES}

Almeida CFM \& Kagan N (2010) Aplicação de algoritmos genéticos e teoria dos conjuntos Fuzzy no dimensionamento de sistemas de monitoração para redes de transmissão de energia elétrica. Revista Controle \& Automação, 21:363-378.

Almeida EA \& Passini R (2013) Thermal comfort in reduced models of broilers' houses, under different types of roofing materials. Engenharia Agrícola, 33:19-27.

Baracho MS, Camargo GA \& Lima AMC (2006) Variables impacting poultry meat quality from production to pre-slaughter: a review. Revista Brasileira de Ciência Avícola, 8:201-212.

Boiago MM, Borba H, Souza PA, Scatolini AM, Ferrari FB \& Giampietro-Ganeco A (2013) Desempenho de frangos de corte alimentados com dietas contendo diferentes fontes de selênio, zinco e manganês, criados sob condições de estresse térmico. Arquivo Brasileiro de Medicina Veterinária e Zootecnia, 65:241247 .

Cobb (2012) Manual de Manejo de Frangos de Corte. Disponível em: <http://wp.ufpel.edu.br/avicultura/files/2012/04/Cobb-Manual-Frango-Corte-BR.pdf>. Acessado em: 05 de abril de 2016.

Cordeiro MB, Tinôco IFF, Silva JN, Vigoderis R, Pinto FAC \& Cecon PR (2010) Conforto térmico e desempenho de pintos de corte submetidos a diferentes sistemas de aquecimento no período de inverno. Revista Brasileira de Zootecnia, 39:217-224.

Cornelissen AMG, Berg JVD, Koops WJ \& Kaymak U (2002) Eliciting expert knowledge for Fuzzy evaluation of agricultural production systems. Disponível em: <file://C:/Users/CERES/ Downloads/erimrs20021125180137\%20(1).pdf>.Acessado em: 07 de março de 2015.

Ferreira L, Yanagi Júnior T, Nääs IA \& Lopes MA (2007) Development of algorithm using Fuzzy logic to predict estrus in dairy cows: Part I. Agricultural Engineering International The CIGR Ejournal, 9:1-16.

Heier BT, Hogasen HR \& Jarp J (2002) Factors associated with mortality in Norwegian broiler flocks. Preventive Veterinary Medicine, 53:147-158.
Leite MS, Fileti AMF \& Silva FV (2010) Desenvolvimento e aplicação experimental de controladores Fuzzy e convencional em um bioprocesso. Revista Controle \& Automação, 21:147-158.

Lopes JCO, Ribeiro MN \& Lima VBS (2015) Estresse por calor em frangos de corte. Revista Eletrônica Nutri-Time, 12:44784487.

Lira RC, Rabello CBV, Ferreira PV, Lana GRQ, Lüdke JV \& Dutra Júnior WM (2009) Inclusion of guava wastes in feed for broiler chickens. Revista Brasileira de Zootecnia, 38:2.401-2.407.

Medeiros CM (2001) Ajuste de modelos e determinação de índice térmico ambiental de produtividade para frangos de corte. Tese de Doutorado. Universidade Federal de Viçosa, Viçosa. 125p.

Medeiros CM, Baêta FC, Oliveira RFM, Tinôco IFF, Albino LFT \& Cecon PR (2005) Efeitos da temperatura, umidade relativa e velocidade do ar em frangos de corte. Engenharia na Agricultura, 13:277-286.

Nääs IA, Romanini CEB, Salgado DD, Lima KAO \& Vale MM (2010) Impact of global warming on beef cattle production cost in Brazil. Scientia Agricola, 67:01-8.

Nascimento GR, Pereira DF, Nääs IA \& Rodrigues LHA (2011) Índice Fuzzy de conforto térmico para frangos de corte. Engenharia Agrícola, 31:219-229.

Oliveira RFM, Donzele JL, Abreu MLT, Ferreira RA, Vaz RGMV \& Cella PS (2006) Efeitos da temperatura e da umidade relativa sobre o desempenho e o rendimento de cortes nobres de frangos de corte de 1 a 49 dias de idade. Revista Brasileira de Zootecnia, 35:797-803.

Pandorfi H, Silva IJO, Guiselini C \& Piedade SMS (2007) Uso da lógica Fuzzy na caracterização do ambiente produtivo para matrizes gestantes. Engenharia Agrícola, 27:83-92.

Pereira DF, Bighi CA, Gabriel Filho LR \& Gabriel CPC (2008) Sistema fuzzy para estimativa do bem-estar de matrizes pesadas. Engenharia Agrícola, 28:624-634.

Ponciano PF, Yanagi Júnior T, Schiassi L, Campos AT \& Nascimento JWB (2012) Sistema fuzzy para predição do desempenho produtivo de frangos de corte de 1 a 21 dias de idade. Engenharia Agrícola, 32:446-458.

Schiassi L, Yanagi Júnior T, Damasceno FA, Saraz JAO \& Machado NS (2012) Fuzzy modeling applied to the welfare of poultry farms workers. Dyna, 174:127-135.

Schiassi L, Yanagi Júnior T, Reis GM, Abreu LHP, Campos AT \& Castro JO (2015) Modelagem Fuzzy aplicada na avaliação do desempenho de frangos de corte. Revista Brasleira de Engenharia Agrícola e Ambiental, 19:140-146.

Silva VK, Silva JDT, Gravena RA, Marques RH, Hada FH \& Moraes VMB (2009) Desempenho de frangos de corte de 1 a 21 dias de idade alimentados com ração contendo extrato de leveduras e prebiótico e criados em diferentes temperaturas. Revista Brasileira de Zootecnia, 38:690-696.

Thon MS, Stringhini JH, Jardim Filho RM, Andrade MA, Café MB \& Leandro NSM (2010) Níveis de proteína e de arginina digestível na ração pré-inicial de frangos de corte. Revista Brasileira de Zootecnia, 39:1.105-1.111.

Tinôco IFF (2004) A granja de frangos de corte. In: Mendes AA, Nääs IA \& Macari M (Eds.) Produção de frangos de corte. Campinas, FACTA. 356p.

Yanagi Júnior T, Schiassi L, Abreu LHP, Barbosa JA \& Campos AT (2012) Procedimento Fuzzy aplicado à avaliação da insalubridade em atividades agrícolas. Engenharia Agrícola, 32:423-434. 